\title{
High-temperature synthesis of a uranyl peroxo complex facilitated by hydrothermally in-situ formed organic peroxide
}

Lei Mei, ${ }^{\dagger,} \S$ Qun-yan Wu, ${ }^{\dagger, \S}$ Si Wu, ${ }^{\dagger,} \S$ Jun-Shan Geng, ${ }^{\dagger}$ Ya-lan Liu,${ }^{\dagger}$ Kong-qiu Hu, ${ }^{\dagger}$ Yi-chuan Liu, ${ }^{\dagger}$ Zhi-hui Zhang, ${ }^{\dagger}$ Yuan-yuan Liang, ${ }^{\dagger}$ Zhi-fang Chai, ${ }^{\dagger, \&}$ Peter C. Burns ${ }^{\uparrow}$ and Wei-qun Shi ${ }^{*}{ }^{\dagger}$

$\dagger$ Laboratory of Nuclear Energy Chemistry, Institute of High Energy Physics, Chinese Academy of Sciences, Beijing 100049, China

\& Engineering Laboratory of Nuclear Energy Materials, Ningbo Institute of Industrial Technology, Chinese Academy of Sciences, Ningbo, Zhejiang Province, 315201, China

$\$$ Jiangsu Key Laboratory of Advanced Catalytic Materials and Technology, Advanced Catalysis and Green Manufacturing Collaborative Innovation Center, Changzhou University, 213164 Changzhou, China

" Department of Civil and Environmental Engineering and Earth Sciences, Department of Chemistry and Biochemistry, University of Notre Dame, Notre Dame, Indiana 46556, United States

*Email: shiwq@ihep.ac.cn

\section{Table of Contents}

\section{S1. Supplementary Methods}

Materials and characterization methods.

Synthesis of HT-UPO1

Single crystal X-ray diffraction.

Theoretical calculations.

\section{S2. Supplementary Figures}

Figure S1. Three uranyl peroxide dimers moieties in HT-UPO1comprising two uranyl centers and a bridging peroxide with the same chemical composition, $\left[\left(\mathrm{UO}_{2}\right)_{2}\left(\mathrm{O}_{2}\right)(\text { Phen })_{2}(\mathbf{P y V B})_{2}\right]$.

Figure S2. Typical molecular orbitals (MOs) for $\left[\left(\mathrm{UO}_{2}\right)_{2}\left(\mathrm{O}_{2}\right)(\mathbf{P h e n})_{2}(\mathbf{P y V B})_{2}\right]-\mathrm{A}$, $\left[\left(\mathrm{UO}_{2}\right)_{2}\left(\mathrm{O}_{2}\right)(\text { Phen })_{2}(\mathbf{P y V B})_{2}\right]-\mathrm{B}$, and $\left[\left(\mathrm{UO}_{2}\right)_{2}\left(\mathrm{O}_{2}\right)(\mathbf{P h e n})_{2}(\mathbf{P y V B})_{2}\right]-\mathrm{C}$ (the first data denotes the orbital number, and the second one in the parentheses is the orbital energy $(\mathrm{eV})$ ).

Figure S3. A typical MO of $\left[\left(\mathrm{UO}_{2}\right)_{2}\left(\mathrm{O}_{2}\right)(\mathbf{P h e n})_{2}(\mathbf{P y V B})_{2}\right]$ motif after structural optimization converged to a final configuration with the dihedral angle of around $148^{\circ}$.

Figure S4. NBO orbitals of $\left[\left(\mathrm{UO}_{2}\right)_{2}\left(\mathrm{O}_{2}\right)(\mathbf{P h e n})_{2}(\mathbf{P y V B})_{2}\right]$ motif with optimized configuration. 
Figure S5. Lattice packing of three sets of uranyl peroxide dimers in HT-UPO1: (a) stacking patterns of different layers, each of which is constructed by only one kind of uranyl peroxide dimers (denoted using the uranium atoms involved, such as U1-U1, U2-U3 and U4-U5); (b) the layered network based on 'U2-U3' dimers cross-linked by weak interactions; (c) intensive hydrogen bonds between adjacent layers with different uranyl dimers; (d) hydrogen bonds involving pyridine and aromatic $\mathrm{C}-\mathrm{H}$ within the layered network; (e) $\pi$ - $\pi$ interactions between Phen groups with average distances of $\sim 3.38 \AA$.

Figure S6. A comparison of crystal structures of hydrothermal products from uranyl with HPyVB (a) or another two other two carboxylic acids with slightly shorter pyridin-4-yl)vinyl skeletons, HP4yA (b) and HP3yA (c).

Figure S7. A schematic diagram for the possible transformation from a dihydroxyl-bridged dimeric uranyl motif to a peoxo-bridged one based on different organic carboxylate ligands, PyVB, P4yA and P3yA. The structures for all these dihydroxyl-bridged and peoxo-bridged dimeric uranyl motifs are optimized. The carboxylate group in each dihydroxyl-bridged motif are monodentate with the dangling carboxyl oxygen atom being stabilized by $\mathrm{O}-\mathrm{H} \cdots \mathrm{O}$ hydrogen bonds. The $\eta^{1}$-coordinated carboxylate group slightly deviates off the equatorial plane of the dimeric uranyl motif with a deflection angle of $17.32^{\circ}, 11.12^{\circ}$ and $9.98^{\circ}$ for $\left[\left(\mathrm{UO}_{2}\right)_{2}(\mathrm{OH})_{2}(\mathbf{P h e n})_{2}(\mathbf{P y V B})_{2}\right], \quad\left[\left(\mathrm{UO}_{2}\right)_{2}(\mathrm{OH})_{2}(\mathbf{P h e n})_{2}(\mathbf{P 4 y A})_{2}\right], \quad$ and $\left[\left(\mathrm{UO}_{2}\right)_{2}(\mathrm{OH})_{2}(\mathbf{P h e n})_{2}(\mathbf{P 3 y A})_{2}\right]$. The dihedral angles of uranyl-peroxide-uranyl moieties of $\left[\left(\mathrm{UO}_{2}\right)_{2}\left(\mathrm{O}_{2}\right)(\mathbf{P h e n})_{2}(\mathbf{P 4 y A})_{2}\right]$, and $\left[\left(\mathrm{UO}_{2}\right)_{2}\left(\mathrm{O}_{2}\right)(\text { Phen })_{2}(\mathbf{P 3 y A})_{2}\right]\left(143.65^{\circ}\right.$ and $\left.143.85^{\circ}\right)$ are similar to that of $\left[\left(\mathrm{UO}_{2}\right)_{2}\left(\mathrm{O}_{2}\right)(\mathbf{P h e n})_{2}(\mathbf{P y V B})_{2}\right]\left(148.01^{\circ}\right)$.

Figure S8. Thermogravimetric analysis (TGA) results of HT-UPO1.

Figure S9. Fluorescence spectra of HT-UPO1 with that of HPyVB as a comparison.

Figure S10. Infrared (IR) spectra of HT-UPO1 with a comparison to HPyVB, showing a typical $\mathrm{U}=\mathrm{O}$ vibration peak at $\sim 882 \mathrm{~cm}^{-1}$. The vibration peak of carboxyl group in HPyVB at $1695 \mathrm{~cm}^{-1}$ is shifted to $1628 \mathrm{~cm}^{-1}$ after coordinating with uranyl in HT-UPO1.

\section{S3. Supplementary Tables}

Table S1. Crystallographic data and structure refinement results for HT-UPO1.

Table S2. Selected bond lengths $(\AA)$ and bond angles $\left({ }^{\circ}\right)$ for HT-UPO1.

Table S3. Typical molecular orbitals for $\left[\left(\mathrm{UO}_{2}\right)_{2}\left(\mathrm{O}_{2}\right)(\text { Phen })_{2}(\mathbf{P y V B})_{2}\right]-\mathrm{A}, \mathrm{B}$ and C.

Table S4. Structural data of three sets of uranyl-peroxide-uranyl moieties in HT-UPO1.

Table S5. Atom compositions of the NBO orbitals of optimized $\left[\left(\mathrm{UO}_{2}\right)_{2}\left(\mathrm{O}_{2}\right)(\text { Phen })_{2}(\mathbf{P y V B})_{2}\right]$ motif.

Table S6. Different energy data for $\left[\left(\mathrm{UO}_{2}\right)_{2}\left(\mathrm{O}_{2}\right)(\mathbf{P h e n})_{2}(\mathbf{P y V B})_{2}\right]$ motif with varying dihedral angles changing from $120^{\circ}$ to $180^{\circ}$ with the configuration at $148^{\circ}$ as a control.

Table S7. Typical hydrogen bond distances $(\AA)$ and angle $\left(^{\circ}\right)$ in HT-UPO1.

Table S8. The change of Gibbs free energies $(\Delta \mathrm{G}, \mathrm{kcal} / \mathrm{mol})$, enthalpies $(\Delta \mathrm{H}, \mathrm{kcal} / \mathrm{mol})$ and entropies $(\Delta \mathrm{S}, \mathrm{kcal} / \mathrm{mol})$ for the reactions $\left(\mathrm{UO}_{2}\right)_{2}\left(\mathrm{O}_{2}\right)(\mathbf{L})_{2}+\mathrm{H}_{2} \mathrm{O}_{2}=\left(\mathrm{UO}_{2}\right)_{2}(\mathrm{OH})_{2}(\mathbf{L})_{2}+2 \mathrm{H}_{2} \mathrm{O}$ at the B3LYP/RECP/6-31G(d) level of theory.

\section{S4. References}




\section{S1. Supplementary Methods}

Materials and characterization methods. Caution! Uranyl nitrate hexahydrate, $\mathrm{UO}_{2}\left(\mathrm{NO}_{3}\right)_{2} \cdot 6 \mathrm{H}_{2} \mathrm{O}$, possessing chemical and radioactive toxicity was used here, and should be handled according to standard precautions with suitable care and protection. (E)-4-(2-(pyridin-4-yl)vinyl)benzoic acid (HPyVB) was prepared by a previously reported method.[1] 1, 10-phenanthroline (Phen) monohydrate and other reagents were analytically pure and used as received. A stock solution of uranyl nitrate $(0.5 \mathrm{M})$ was prepared by dissolving certain amounts of $\mathrm{UO}_{2}\left(\mathrm{NO}_{3}\right)_{2} \cdot 6 \mathrm{H}_{2} \mathrm{O}$ in deionized water before used.

${ }^{1} \mathrm{H}-\mathrm{NMR}$ spectra were recorded on a Bruker AVANCE III (500 MHz, Bruker, Switzerland) with deuterium oxide as a solvent. ESI-MS spectra were obtained with a Bruker AmaZon SL ion trap mass spectrometer (Bruker, USA). The Raman spectra were recorded on a confocal Raman spectrometer with a $473 \mathrm{~nm}$ argon ion laser. Solid-state fluorescence spectra were measured on a Hitachi F-4600 fluorescence spectrophotometer. The thermogravimetric analyses (TGA) were recorded on a TA Q500 analyser over the temperature range of $25-800{ }^{\circ} \mathrm{C}$ in an air atmosphere with a heating rate of $5{ }^{\circ} \mathrm{C}$ per minute. The Fourier transform infrared (IR) spectra were recorded on a Bruker Tensor 27 spectrometer. The fluorescence spectra were measured on a Hitachi F-4700 fluorescence spectrophotometer equipped with a xenon lamp and solid sample holder.

Synthesis of HT-UPO1. $0.5 \mathrm{M} \mathrm{UO}_{2}\left(\mathrm{NO}_{3}\right)_{2} \cdot 6 \mathrm{H}_{2} \mathrm{O}$ aqueous solution (200 uL, 0.1 mmol, 1 equiv) was added to a suspension of HPyVB (22.5 mg, $0.1 \mathrm{mmol}, 1$ equiv) and Phen monohydrate $(19.8 \mathrm{mg}, 0.1 \mathrm{mmol}, 1$ equiv) in water $(2 \mathrm{~mL})$ and DMF $(0.5$ $\mathrm{mL}$ ) in a $15 \mathrm{ml}$ stainless-steel vessel, followed by the addition of $1 \mathrm{M} \mathrm{NaOH}$ aqueous solution. The mixture was sealed, and kept at $150{ }^{\circ} \mathrm{C}$ for $48 \mathrm{~h}$, and then cooled to room temperature slowly. Yellow block crystals of HT-UPO1 are filtered off, rinsed with water, and dried in air at room temperature.

For the synthesis of HT-UPO1 using ${ }^{18} \mathrm{O}$-enriched water, the reaction volume was 
reduced in half, and a total of $20 \%$ isotopically neutral water was replaced by ${ }^{18} \mathrm{O}$-enriched water to serve as the aqueous media for the hydrothermal reaction.

Single crystal X-ray diffraction. X-ray single crystal structure determination was acquired on a Bruker D8 VENTURE X-ray CMOS diffractometer with a Mo Ka X-ray source $(\lambda=0.71073 \AA)$ for HT-UPO1. Data frames were collected using the program APEX 3 and processed using the program SAINT routine in APEX 3. The crystal structure was solved by means of direct methods on SHELXS-97 ${ }^{[2]}$, and refined with full-matrix least squares on by using SHELXL program ${ }^{[2-3]}$ using Olex2. ${ }^{[4]}$ The crystal data of HT-UPO1 is given in Table S1. Crystallographic data in this work have been deposited with Cambridge Crystallographic Data Centre, and the CCDC number is 2044690 .

Theoretical calculations. The density functional theory (DFT) calculations were carried out with the B3LYP ${ }^{[5]}$ hybrid functional by using the Gaussian 16 program. ${ }^{[6]}$ The structures of $\left(\mathrm{UO}_{2}\right)_{2}\left(\mathrm{O}_{2}\right)(\mathbf{P h e n})_{2}(\mathbf{P y V B})_{2}$ complexes obtained from the corresponding X-ray crystal were optimized. The quasi-relativistic pseudo-potential $\mathrm{ECP} 6 \mathrm{MWB}^{[7]}$ and the associated ECP60MWB-SEG valence basis set ${ }^{[8]}$ was used to describe for $\mathrm{U}$ atom, the 6-31G(d) basis set was used for the other light atoms $\mathrm{H}, \mathrm{C}, \mathrm{N}$ and O. The molecule orbitals of $\left(\mathrm{UO}_{2}\right)_{2}\left(\mathrm{O}_{2}\right)(\text { Phen })_{2}(\mathbf{P y V B})_{2}-\mathrm{A}, \mathrm{B}, \mathrm{C}$ complexes were plotted with the GaussView 6 . The optimizations for the complexes studied here were performed at the B3LYP/ECP60MWB/6-31G(d) level of theory in the gas phase. The scan of the potential energy surface for the dihedral angle $\left(\mathrm{U}-\mathrm{O}_{2}-\mathrm{U}\right)$ changing from $120^{\circ}$ to $180^{\circ}$ were obtained to confirm which structure is the most stable.

To investigate the bonding nature between the oxygen atom and uranium, natural population analysis (NPA) was performed by using NBO 6.0 program $^{[9]}$ as implemented in the Amsterdam density functional (ADF 2013.01) package. ${ }^{[10]}$ In NBO calculations, BP86 method and the Slater type orbital (STO) basis set TZP were used, ${ }^{[11]}$ without the frozen core. The scalar relativistic (SR) effects were taken into account using the zero-order regular approximation (ZORA) approach. ${ }^{[12]}$ The natural 
bonding orbitals of U-O bonds were explored at the BP86/ZORA/TZP level of theory using ADF based on the optimized structures at the B3LYP/ECP60MWB/6-31G(d) level of theory. In addition, to evaluate the stability of the uranyl peroxide species with three different ligand PyVB, HP4yA and HP3yA, the thermodynamic properties of the reactions $\left.\mathrm{UO}_{2}\right)_{2}\left(\mathrm{O}_{2}\right)(\mathbf{L})_{2}+\mathrm{H}_{2} \mathrm{O}_{2}=\left(\mathrm{UO}_{2}\right)_{2}(\mathrm{OH})_{2}(\mathbf{L})_{2}+2 \mathrm{H}_{2} \mathrm{O}$ were calculated at the B3LYP/ ECP60MWB /6-31G(d) level of theory. 


\section{S2. Supplementary Figures}

(a) $\left[\left(\mathrm{UO}_{2}\right)_{2}\left(\mathrm{O}_{2}\right)(\text { Phen })_{2}(\text { PyVB })_{2}\right]-\mathrm{A}$
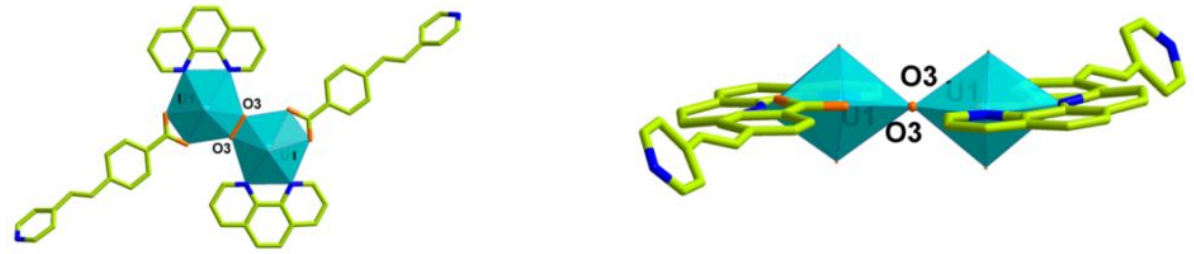

(b) $\left[\left(\mathrm{UO}_{2}\right)_{2}\left(\mathrm{O}_{2}\right)(\text { Phen })_{2}(\text { PyVB })_{2}\right]-\mathrm{B}$
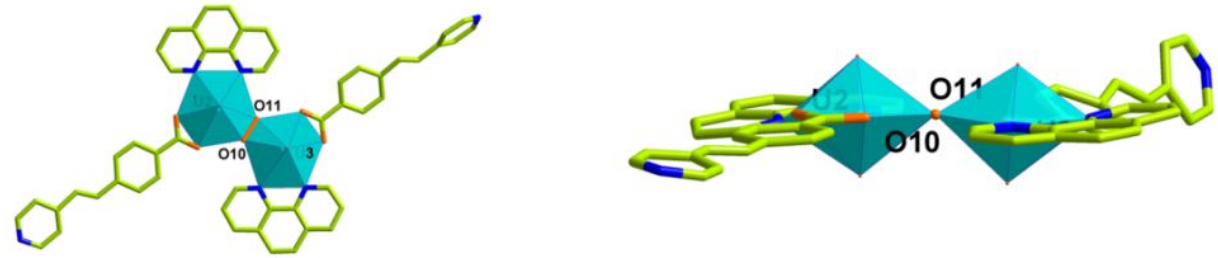

(c) $\left[\left(\mathrm{UO}_{2}\right)_{2}\left(\mathrm{O}_{2}\right)(\text { Phen })_{2}(\text { PyVB })_{2}\right]-\mathrm{C}$
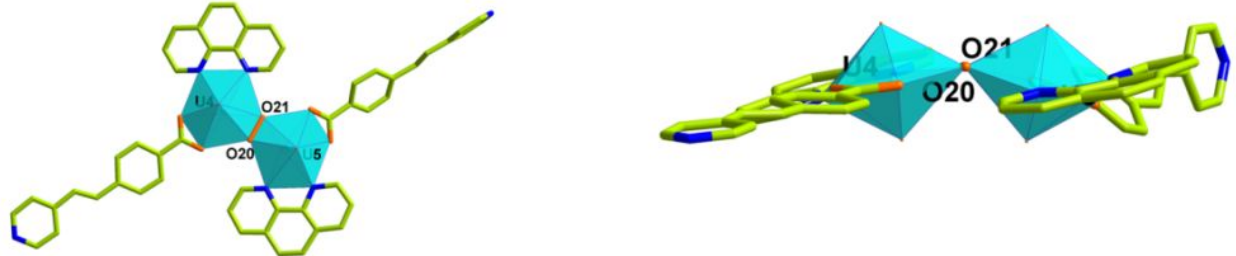

Figure S1. Three uranyl peroxide dimers moieties in HT-UPO1 comprising two uranyl centers and a bridging peroxide with the same chemical composition, $\left[\left(\mathrm{UO}_{2}\right)_{2}\left(\mathrm{O}_{2}\right)(\mathbf{P h e n})_{2}(\mathbf{P y V B})_{2}\right]$. 


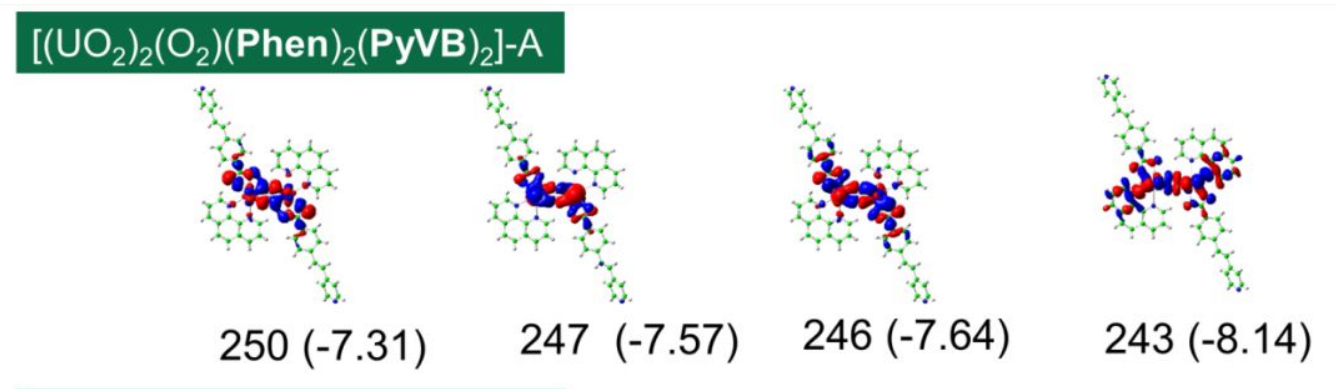

\section{$\left[\left(\mathrm{UO}_{2}\right)_{2}\left(\mathrm{O}_{2}\right)(\text { Phen })_{2}(\text { PyVB })_{2}\right]-\mathrm{B}$}

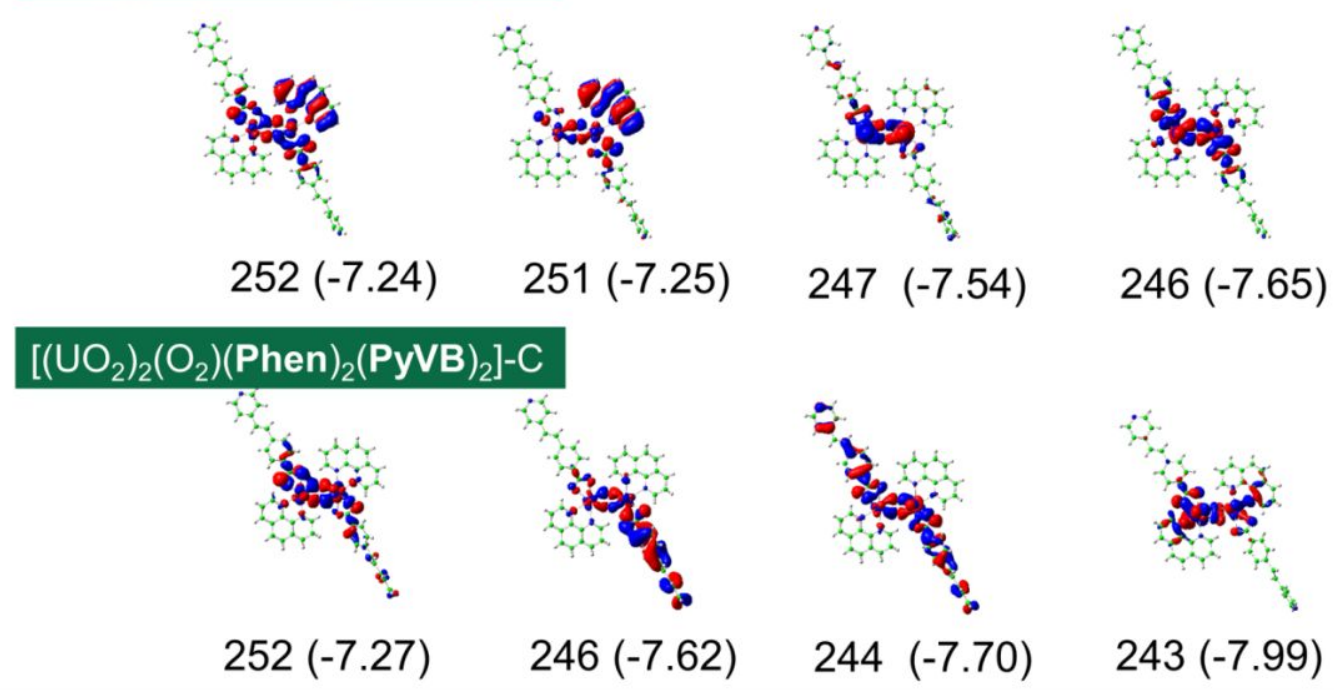

Figure S2. Typical molecular orbitals (MOs) for $\left[\left(\mathrm{UO}_{2}\right)_{2}\left(\mathrm{O}_{2}\right)(\mathbf{P h e n})_{2}(\mathbf{P y V B})_{2}\right]-\mathrm{A}$, $\left[\left(\mathrm{UO}_{2}\right)_{2}\left(\mathrm{O}_{2}\right)(\mathbf{P h e n})_{2}(\mathbf{P y V B})_{2}\right]-\mathrm{B}$, and $\left[\left(\mathrm{UO}_{2}\right)_{2}\left(\mathrm{O}_{2}\right)(\text { Phen })_{2}(\mathbf{P y V B})_{2}\right]-\mathrm{C}$ (the first data denotes the orbital number, and the second one in the parentheses is the orbital energy $(\mathrm{eV}))$. 


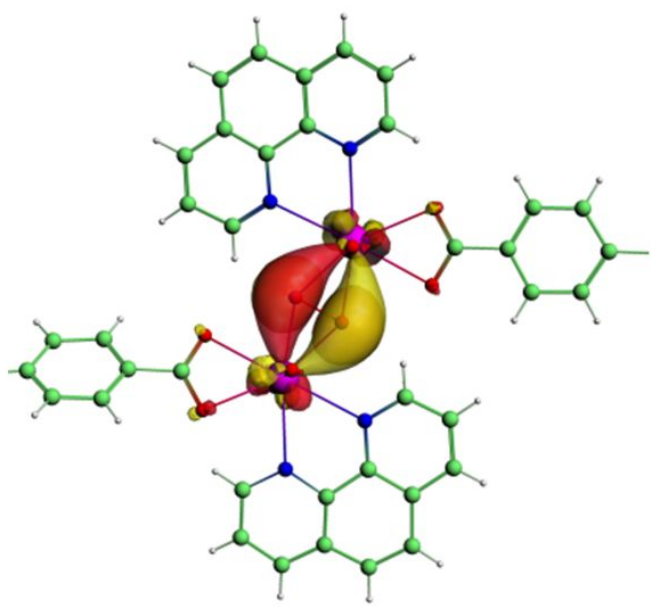

2 UOU $\pi$

Selected MO of $\left[\left(\mathrm{UO}_{2}\right)_{2}\left(\mathrm{O}_{2}\right)(\text { Phen })_{2}(\text { PyVB })_{2}\right]$

Figure S3. A typical MO of $\left[\left(\mathrm{UO}_{2}\right)_{2}\left(\mathrm{O}_{2}\right)(\mathbf{P h e n})_{2}(\mathbf{P y V B})_{2}\right]$ motif after structural optimization converged to a final configuration with the dihedral angle of around $148^{\circ}$.

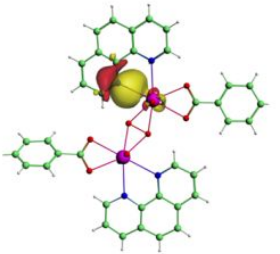

U-N $\sigma$

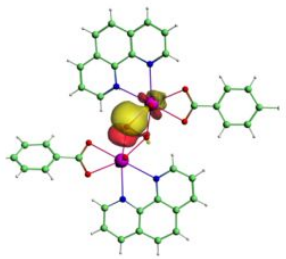

$\mathrm{U}-\mathbf{O} \sigma$

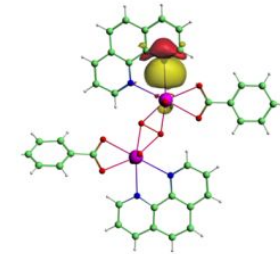

U-N $\sigma$

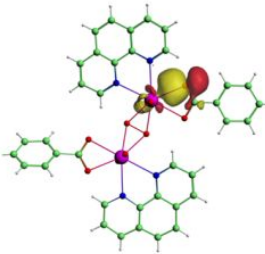

$\mathbf{U}-\mathbf{O} \sigma$

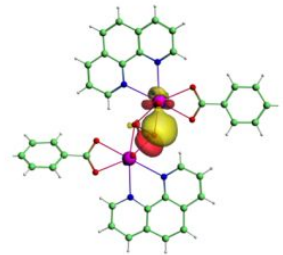

$\mathbf{U}-\mathbf{O} \sigma$

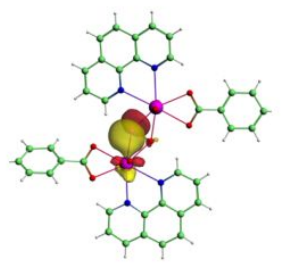

U-O $\sigma$

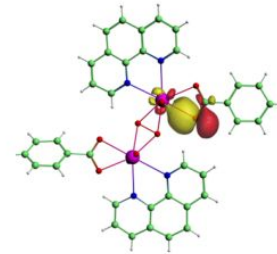

U-O $\sigma$

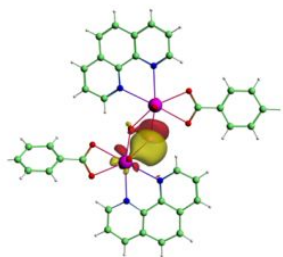

U-O $\sigma$

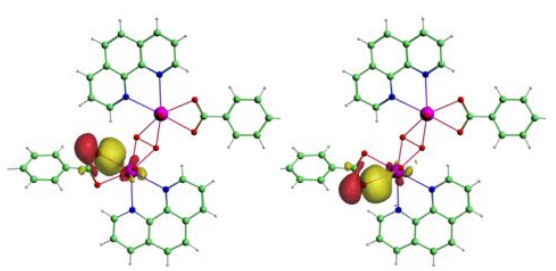

U-O $\sigma$

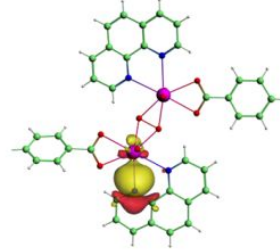

U-N $\sigma$

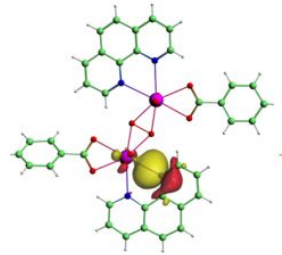

U-N $\sigma$

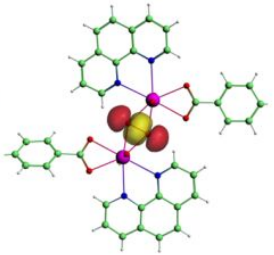

O-O $\sigma$

Figure S4. NBO analysis of $\left[\left(\mathrm{UO}_{2}\right)_{2}\left(\mathrm{O}_{2}\right)(\mathbf{P h e n})_{2}(\mathbf{P y V B})_{2}\right]$ motif with optimized configuration. 
(a)

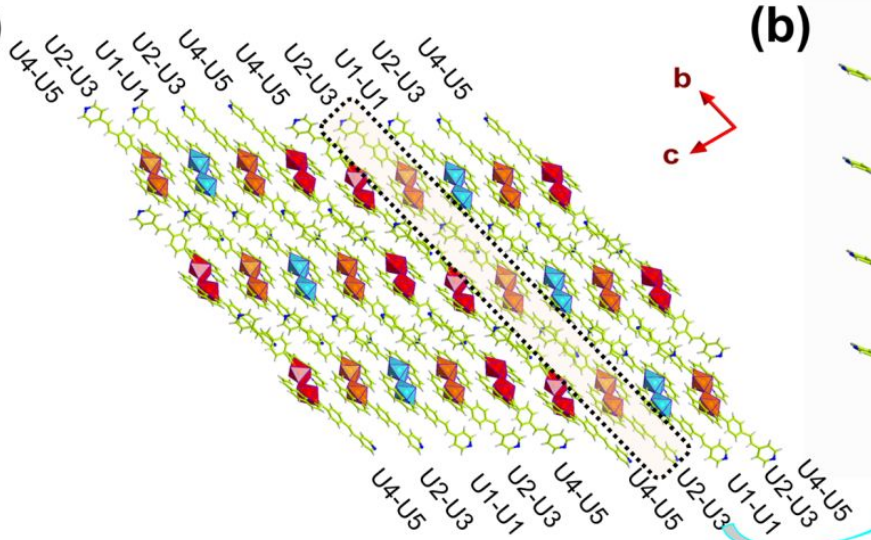

(b)

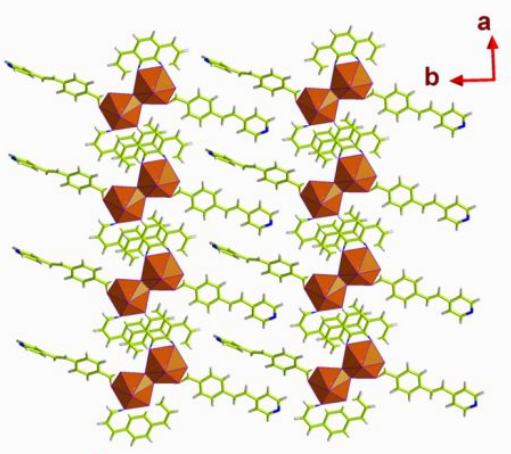

Layered network based on'U2-U3' uranyl dimer
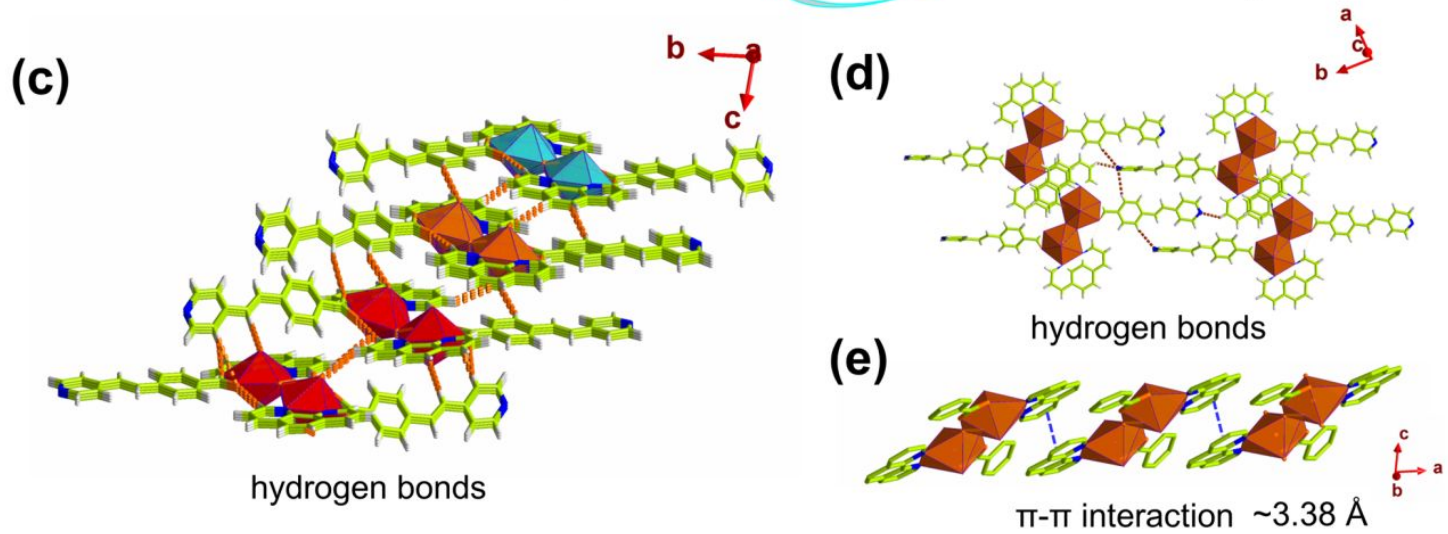

Figure S5. Lattice packing of three sets of uranyl peroxide dimers in HT-UPO1: (a) stacking patterns of different layers, each of which is constructed by only one kind of uranyl peroxide dimers (denoted using the uranium atoms involved, such as U1-U1, U2-U3 and U4-U5); (b) the layered network based on 'U2-U3' dimers cross-linked by weak interactions; (c) intensive hydrogen bonds between adjacent layers with different uranyl dimers; (d) hydrogen bonds involving pyridine and aromatic $\mathrm{C}-\mathrm{H}$ within the layered network; (e) $\pi-\pi$ interactions between Phen groups with average distances of $\sim 3.38 \AA$. 
(a)
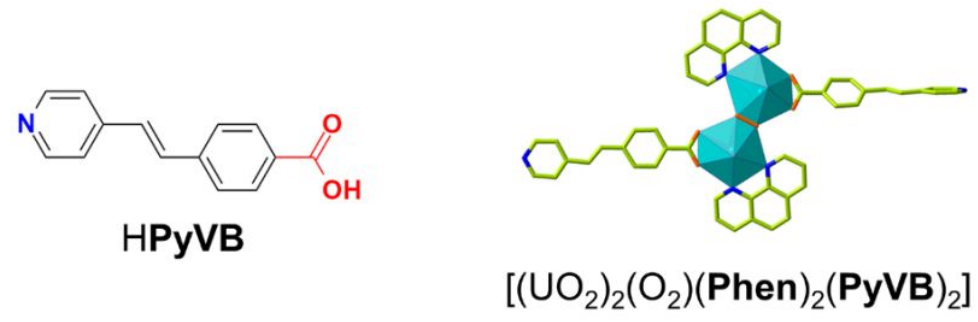

(b)
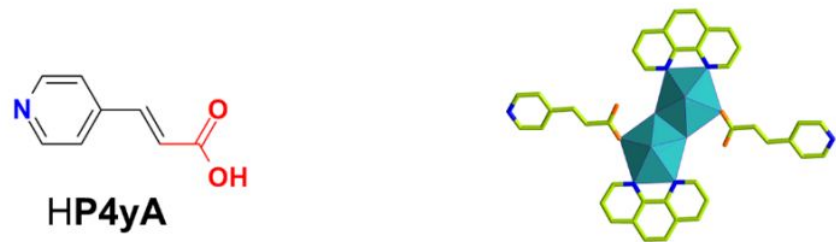

$$
\left[\left(\mathrm{UO}_{2}\right)_{2}(\mathrm{OH})_{2}(\mathrm{Phen})_{2}(\mathrm{P} 4 \mathrm{yA})_{2}\right]
$$

(c)
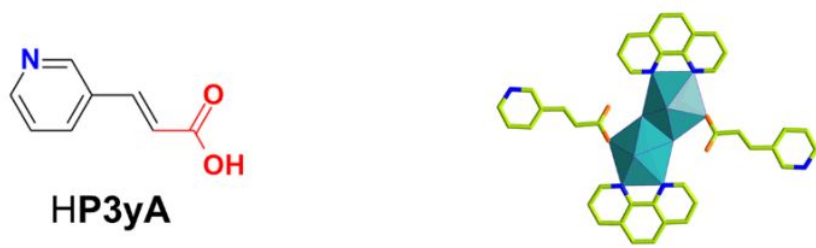

$\left[\left(\mathrm{UO}_{2}\right)_{2}(\mathrm{OH})_{2}(\mathrm{Phen})_{2}(\mathrm{P} 3 \mathrm{yA})_{2}\right]$

Figure S6. A comparison of crystal structures of hydrothermal products from uranyl with HPyVB (a) or another two other two carboxylic acids with slightly shorter pyridin-4-yl)vinyl skeletons, HP4yA (b) and HP3yA (c). 


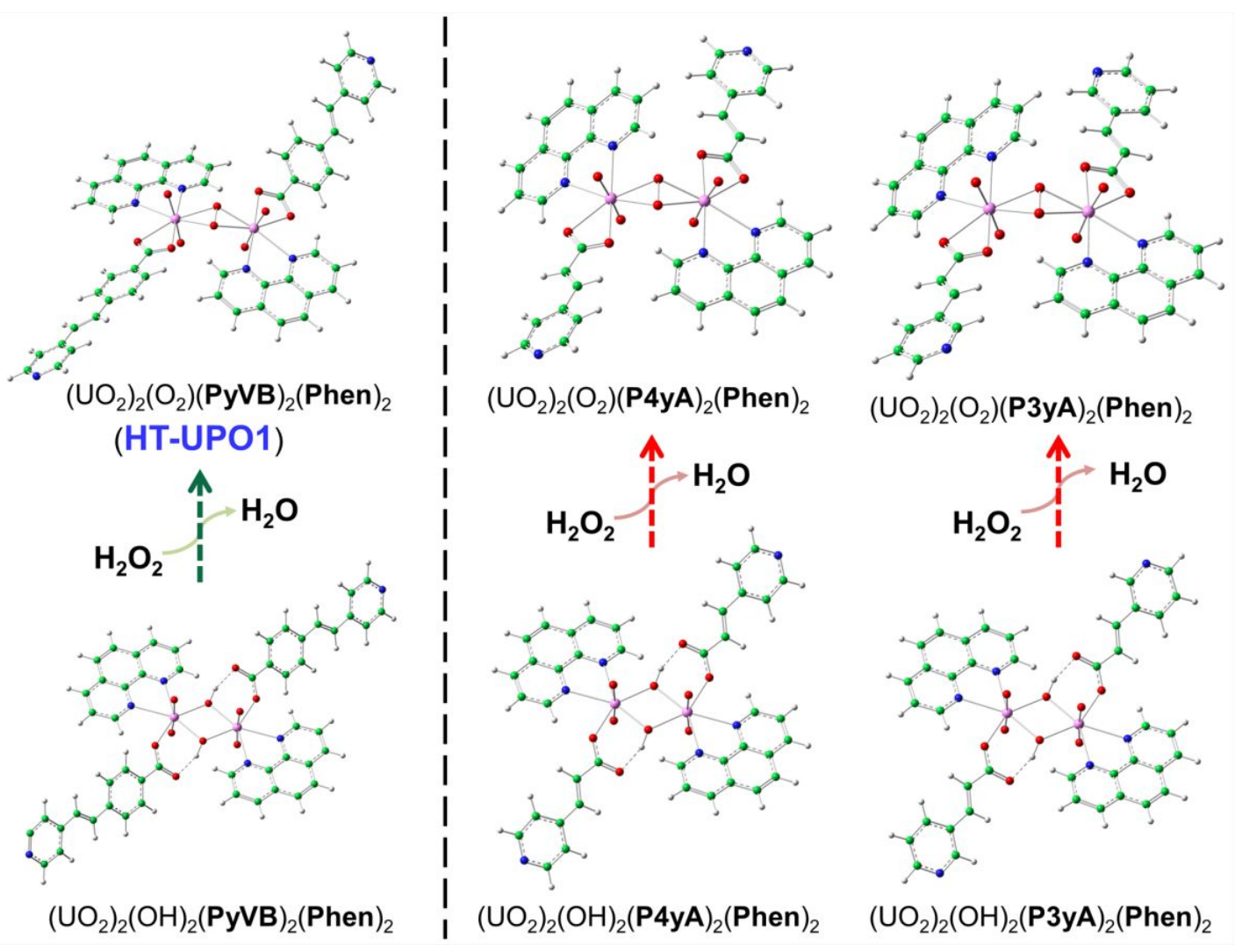

Figure S7. A schematic diagram for the possible transformation from a dihydroxyl-bridged dimeric uranyl motif to a peoxo-bridged one based on different organic carboxylate ligands, PyVB, P4yA and P3yA. The structures for all these dihydroxyl-bridged and peoxo-bridged dimeric uranyl motifs are optimized. The carboxylate group in each dihydroxyl-bridged motif are monodentate with the dangling carboxyl oxygen atom being stabilized by $\mathrm{O}-\mathrm{H} \cdots \mathrm{O}$ hydrogen bonds. The $\eta^{1}$-coordinated carboxylate group slightly deviates off the equatorial plane of the dimeric uranyl motif with a deflection angle of $17.32^{\circ}, 11.12^{\circ}$ and $9.98^{\circ}$ for $\left[\left(\mathrm{UO}_{2}\right)_{2}(\mathrm{OH})_{2}(\text { Phen })_{2}(\mathbf{P y V B})_{2}\right], \quad\left[\left(\mathrm{UO}_{2}\right)_{2}(\mathrm{OH})_{2}(\mathbf{P h e n})_{2}(\mathbf{P 4 y A})_{2}\right], \quad$ and $\left[\left(\mathrm{UO}_{2}\right)_{2}(\mathrm{OH})_{2}(\mathbf{P h e n})_{2}(\mathbf{P 3 y A})_{2}\right]$. The dihedral angles of uranyl-peroxide-uranyl moieties of $\left[\left(\mathrm{UO}_{2}\right)_{2}\left(\mathrm{O}_{2}\right)(\mathbf{P h e n})_{2}(\mathbf{P 4 y A})_{2}\right]$, and $\left[\left(\mathrm{UO}_{2}\right)_{2}\left(\mathrm{O}_{2}\right)(\mathbf{P h e n})_{2}(\mathbf{P 3 y A})_{2}\right]\left(143.65^{\circ}\right.$ and $\left.143.85^{\circ}\right)$ are similar to that of $\left[\left(\mathrm{UO}_{2}\right)_{2}\left(\mathrm{O}_{2}\right)(\mathbf{P h e n})_{2}(\mathbf{P y V B})_{2}\right]\left(148.01^{\circ}\right)$. 


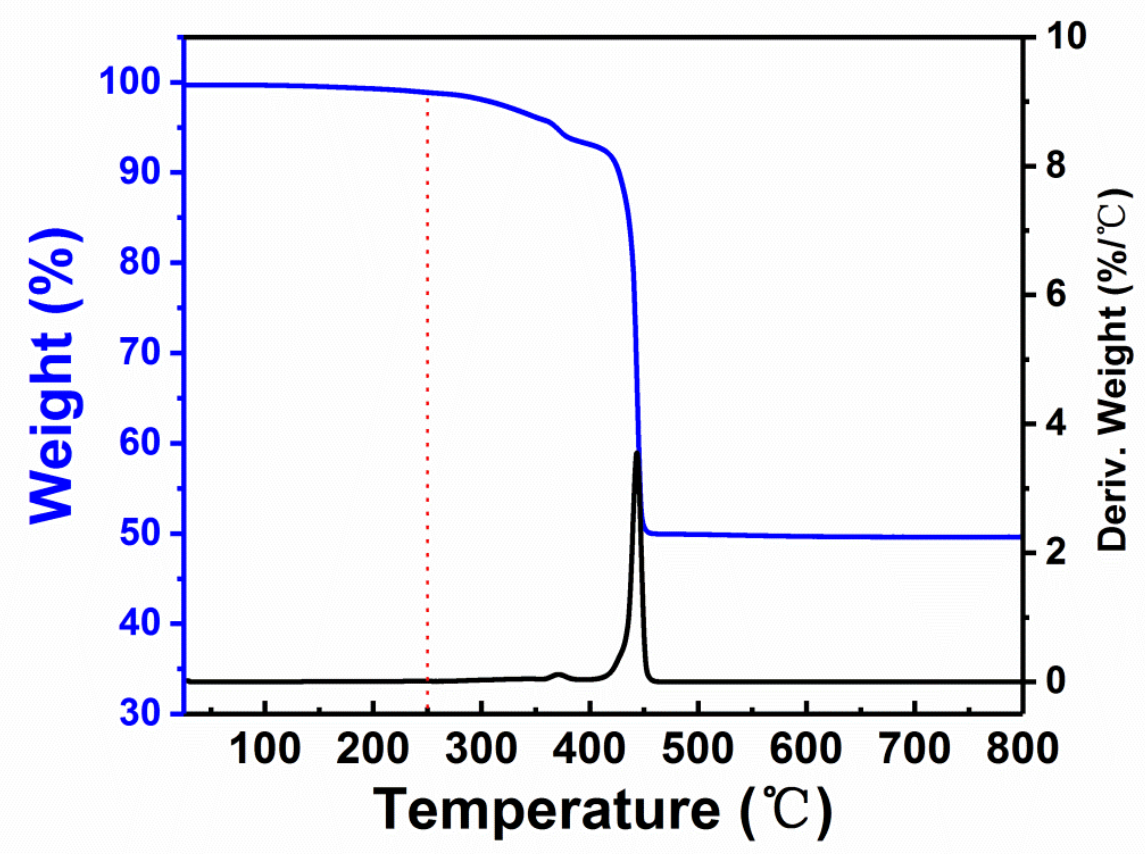

Figure S8. Thermogravimetric analysis (TGA) results of HT-UPO1 exhibiting good thermal stability (red dashed line is corresponding to $250^{\circ} \mathrm{C}$ ).

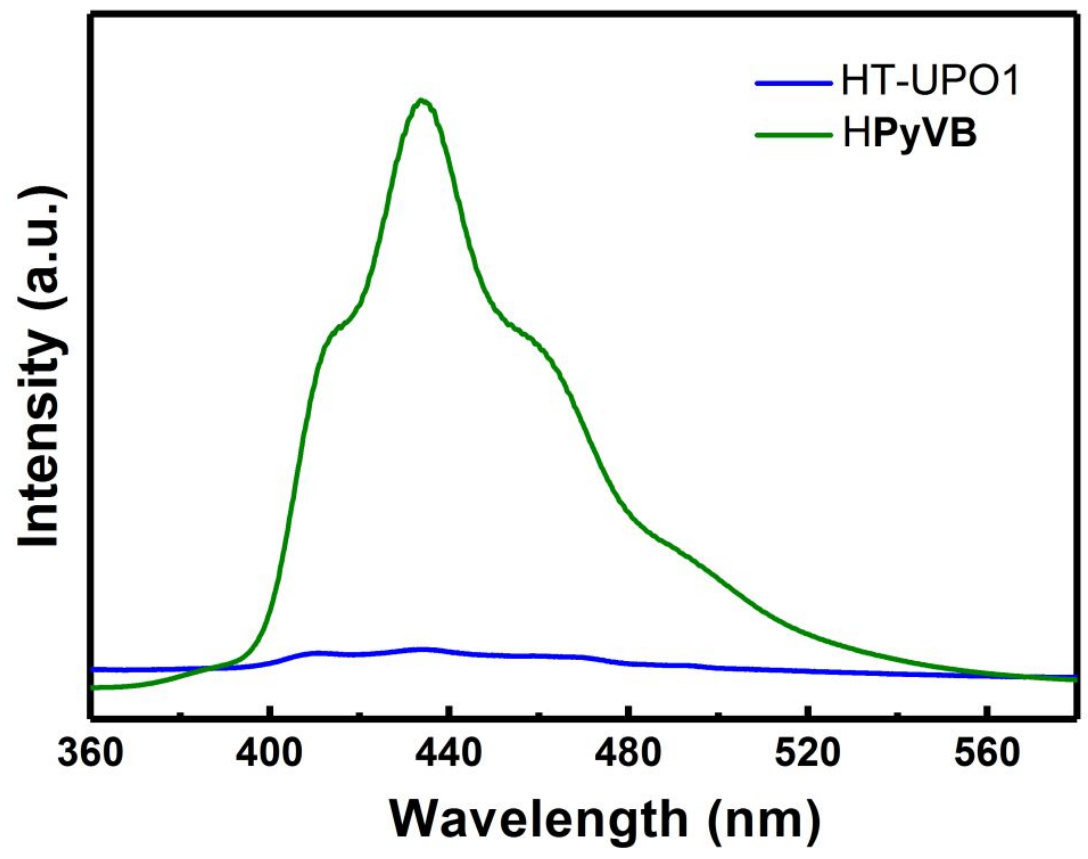

Figure S9. Fluorescence spectra of HT-UPO1 with that of HPyVB as a comparison. 


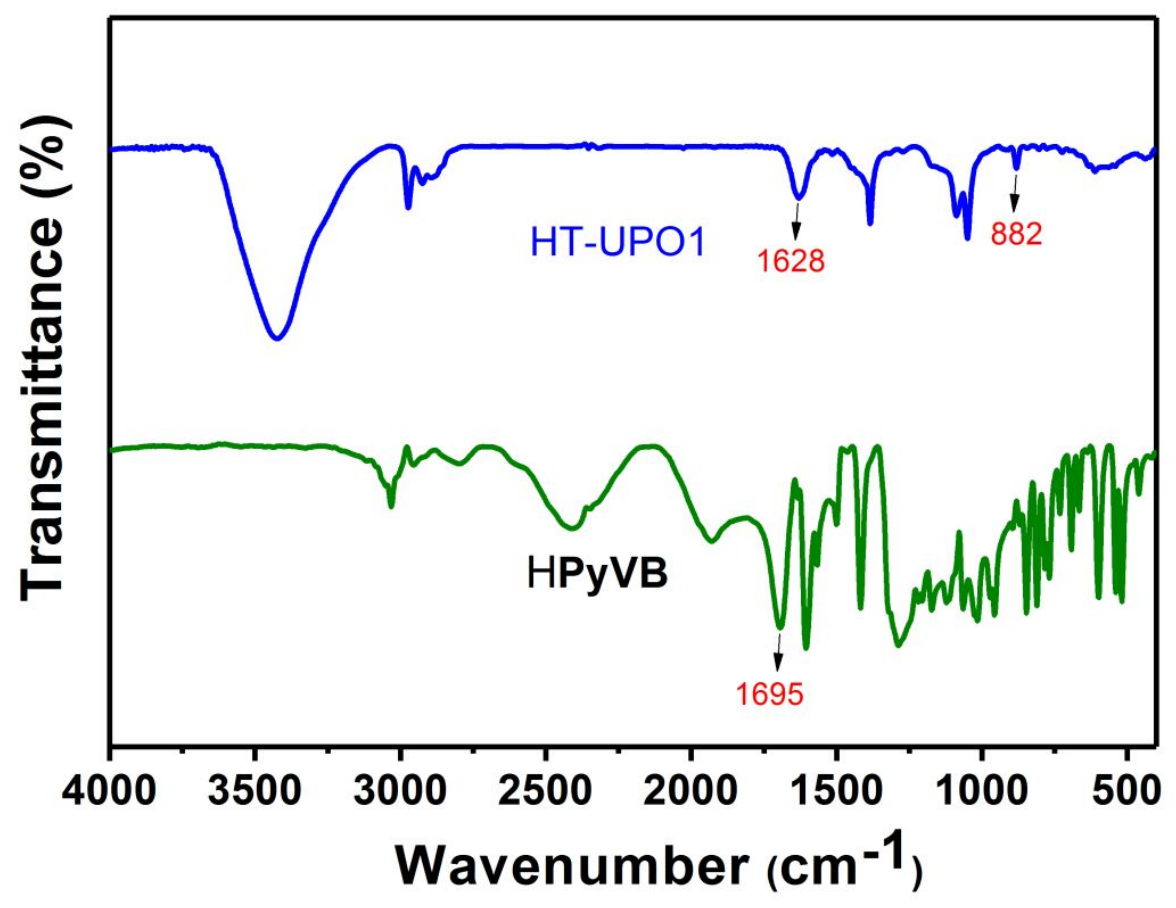

Figure S10. Infrared (IR) spectra of HT-UPO1 with a comparison to HPyVB, showing a typical $\mathrm{U}=\mathrm{O}$ vibration peak at $\sim 882 \mathrm{~cm}^{-1}$. The vibration peak of carboxyl group in HPyVB at $1695 \mathrm{~cm}^{-1}$ is shifted to $1628 \mathrm{~cm}^{-1}$ after coordinating with uranyl in HT-UPO1. 


\section{S3. Supplementary Tables}

Table S1. Crystallographic data and structure refinement results for HT-UPO1.

HT-UPO1

\begin{tabular}{|c|c|}
\hline components & {$\left[\left(\mathrm{UO}_{2}\right)_{2}\left(\mathrm{O}_{2}\right)(\text { Phen })_{2}(\text { PyVB })_{2}\right]_{0.5} \cdot\left[\left(\mathrm{UO}_{2}\right)_{2}\left(\mathrm{O}_{2}\right)(\text { Phen })_{2}(\text { PyVB })_{2}\right] \cdot\left[\left(\mathrm{UO}_{2}\right)_{2}\left(\mathrm{O}_{2}\right)(\text { Phen })_{2}(\text { PyVB })_{2}\right]$} \\
\hline formula & {$\left[\mathrm{C}_{52} \mathrm{H}_{36} \mathrm{~N}_{6} \mathrm{O}_{10} \mathrm{U}_{2}\right]_{\mathrm{n}}$} \\
\hline fw & 1380.93 \\
\hline crystal system & triclinic \\
\hline space group & $P 1$ \\
\hline$T, \mathrm{~K}$ & 276.53 \\
\hline$a, \AA$ & $10.2258(3)$ \\
\hline$b, \AA$ & $21.5561(7)$ \\
\hline$c, \AA$ & $26.4228(8)$ \\
\hline$\alpha$, degree & $82.766(2)$ \\
\hline$\beta$, degree & $81.9630(10)$ \\
\hline$\gamma$, degree & $88.0240(10)$ \\
\hline$V, \AA^{3}$ & $5720.4(3)$ \\
\hline$F(000)$ & 3270.0 \\
\hline$D \mathrm{c}\left(\mathrm{g} \mathrm{cm}^{-3}\right)$ & 2.004 \\
\hline$\mu\left(\mathrm{mm}^{-1}\right)$ & 7.138 \\
\hline$R_{\mathrm{int}}$ & 0.0977 \\
\hline GooF (S) & 1.029 \\
\hline \multicolumn{2}{|l|}{$R_{1}, w R_{2}(\mathrm{I}>=2 \sigma$} \\
\hline (I)) & $0.0617,0.1292$ \\
\hline \multicolumn{2}{|l|}{$R_{1}, w R_{2}$ (all } \\
\hline data) & $0.1190,0.1549$ \\
\hline
\end{tabular}


Table S2. Selected bond lengths $(\AA)$ and bond angles $\left({ }^{\circ}\right)$ for HT-UPO1.

\begin{tabular}{|c|c|c|c|}
\hline Type & lengths $(\AA)$ or angles $\left(^{\circ}\right)$ & Type & lengths $(\AA)$ or angles $\left({ }^{\circ}\right)$ \\
\hline $\mathrm{U} 1=\mathrm{O} 1$ & $1.752(10)$ & $\mathrm{U} 1=\mathrm{O} 2$ & $1.757(11)$ \\
\hline U1-O3 & $2.303(11)$ & $\mathrm{U} 1-\mathrm{O} 3^{1}$ & $2.306(11)$ \\
\hline U1-O4 & $2.503(9)$ & U1-O5 & $2.497(10)$ \\
\hline U1-N1 & $2.644(10)$ & U1-N2 & $2.664(12)$ \\
\hline $\mathrm{O} 1=\mathrm{U} 1=\mathrm{O} 2$ & $174.8(5)$ & & \\
\hline $\mathrm{U} 2=\mathrm{O} 6$ & $1.760(10)$ & $\mathrm{U} 2=\mathrm{O} 7$ & $1.742(10)$ \\
\hline $\mathrm{U} 2-\mathrm{O} 10$ & $2.300(11)$ & U2-O11 & $2.315(11)$ \\
\hline $\mathrm{U} 2-\mathrm{O} 12$ & $2.501(8)$ & $\mathrm{U} 2-\mathrm{O} 13$ & $2.484(10)$ \\
\hline $\mathrm{U} 2-\mathrm{N} 4$ & $2.646(10)$ & U2-N5 & $2.678(11)$ \\
\hline $\mathrm{O} 6=\mathrm{U} 2=\mathrm{O} 7$ & $176.0(5)$ & & \\
\hline $\mathrm{U} 3=\mathrm{O} 8$ & $1.764(11)$ & $\mathrm{U} 3=\mathrm{O} 9$ & $1.723(11)$ \\
\hline U3-O10 & $2.318(11)$ & U3-O11 & $2.288(11)$ \\
\hline U3-O14 & $2.525(11)$ & $\mathrm{U} 3-\mathrm{O} 15$ & $2.485(9)$ \\
\hline U3-N6 & $2.630(11)$ & U3-N7 & $2.632(10)$ \\
\hline $\mathrm{O} 8=\mathrm{U} 3=\mathrm{O} 9$ & $174.6(5)$ & & \\
\hline $\mathrm{U} 4=\mathrm{O} 16$ & $1.778(11)$ & $\mathrm{U} 4=\mathrm{O} 17$ & $1.813(12)$ \\
\hline $\mathrm{U} 4-\mathrm{O} 20$ & $2.326(11)$ & $\mathrm{U} 4-\mathrm{O} 21$ & $2.289(12)$ \\
\hline $\mathrm{U} 4-\mathrm{O} 22$ & $2.519(9)$ & $\mathrm{U} 4-\mathrm{O} 23$ & $2.438(10)$ \\
\hline U4-N10 & $2.618(12)$ & U4-N11 & $2.654(12)$ \\
\hline $\mathrm{O} 16=\mathrm{U} 4=\mathrm{O} 17$ & 174.0(6) & & \\
\hline $\mathrm{U} 5=\mathrm{O} 18$ & $1.764(11)$ & $\mathrm{U} 5=\mathrm{O} 19$ & $1.723(11)$ \\
\hline $\mathrm{U} 5-\mathrm{O} 20$ & $2.338(12)$ & $\mathrm{U} 5-\mathrm{O} 21$ & $2.341(12)$ \\
\hline U5-O24 & $2.498(12)$ & $\mathrm{U} 5-\mathrm{O} 25$ & $2.488(11)$ \\
\hline U5-N12 & $2.630(11)$ & U5-N13 & $2.632(10)$ \\
\hline $\mathrm{O} 8=\mathrm{U} 5=\mathrm{O} 9$ & $174.6(5)$ & & \\
\hline
\end{tabular}


Table S3. Typical molecular orbitals for $\left[\left(\mathrm{UO}_{2}\right)_{2}\left(\mathrm{O}_{2}\right)(\mathbf{P h e n})_{2}(\mathbf{P y V B})_{2}\right]$-A, B and C.

\begin{tabular}{|c|c|c|c|c|c|c|c|c|c|c|c|c|}
\hline & $\mathrm{E} / \mathrm{eV}$ & U1 sim & U2 sim & O3 sim & $\mathrm{O} 4 \operatorname{sim}$ & N6 sim & O7 sim & $\mathrm{O} 8 \mathrm{sim}$ & N9 sim & $\mathrm{N} 10 \mathrm{sim}$ & O11 sim & $\mathrm{O} 12 \mathrm{sim}$ \\
\hline \multicolumn{13}{|c|}{$\left[\left(\mathrm{UO}_{2}\right)_{2}\left(\mathrm{O}_{2}\right)(\mathbf{P h e n})_{2}(\mathbf{P y V B})_{2}\right]-\mathrm{A}$} \\
\hline MO-267 & -5.64 & 3.96 & 3.96 & 44.11 & 44.11 & & & & & & & \\
\hline 250 & -7.31 & 7 & 7.01 & 16.6 & 16.61 & & 15.32 & 3.37 & & & 15.28 & \\
\hline 247 & -7.57 & 23.94 & 23.95 & 5.06 & 5.06 & & & & & & & \\
\hline 246 & -7.64 & 10.28 & 10.29 & 11.02 & 11.02 & & 11.05 & 4.95 & & & 11.05 & \\
\hline 243 & -8.14 & 7.11 & 7.11 & 5.53 & 5.53 & 9.71 & 2.66 & & & 9.71 & 2.66 & \\
\hline \multicolumn{13}{|c|}{$\left[\left(\mathrm{UO}_{2}\right)_{2}\left(\mathrm{O}_{2}\right)(\mathbf{P h e n})_{2}(\mathbf{P y V B})_{2}\right]-\mathrm{B}$} \\
\hline MO-267 & -5.68 & 3.8 & 3.97 & 43.91 & 44.51 & & & & & & & \\
\hline 252 & -7.24 & 3.76 & 3.77 & 9.02 & 8.08 & & 8.67 & 5.77 & & & 10.7 & \\
\hline 251 & -7.25 & 2.24 & 3.74 & & 5.41 & 3.45 & 12.37 & & & & 3.2 & \\
\hline 247 & -7.54 & 26.33 & 22.89 & 4.3 & 4.91 & & & & & & 9.82 & 3.92 \\
\hline 246 & -7.65 & 9.46 & 9.39 & 13.71 & 16.22 & & & 4.24 & & & & \\
\hline \multicolumn{13}{|c|}{$\left[\left(\mathrm{UO}_{2}\right)_{2}\left(\mathrm{O}_{2}\right)(\text { Phen })_{2}(\mathbf{P y V B})_{2}\right]-\mathrm{C}$} \\
\hline MO-267 & -5.84 & 4.43 & 3.91 & 44.96 & 41.94 & & & & & & & \\
\hline 252 & -7.27 & 5.88 & 7.24 & 15.98 & 14.36 & & 5.72 & 16.7 & & & 10.03 & \\
\hline 246 & -7.62 & 2.09 & 3.66 & 8.96 & 3.3 & & & & & & 4.4 & 17.9 \\
\hline 244 & -7.70 & 3.4 & 6.67 & 7.46 & 8.49 & & 3.15 & 9.75 & & & 10.54 & \\
\hline 243 & -7.99 & 13.97 & 4.19 & 2.2 & 3.67 & 4.28 & 3.05 & 6.47 & 4.53 & & & \\
\hline
\end{tabular}


Table S4. Structural data of three sets of uranyl-peroxide-uranyl moieties in HT-UPO1.

\begin{tabular}{|c|c|c|c|c|}
\hline $\begin{array}{c}\text { Uranyl } \\
\text { peroxide dimer }\end{array}$ & $\mathrm{O}-\mathrm{O}$ & $\alpha$ & & \\
\hline \multirow{4}{*}{$\mathrm{U} 1-\left[\mathrm{O}_{2}\right]-\mathrm{U} 1$} & \multirow{4}{*}{$1.461(16)$} & \multirow{4}{*}{$180^{\circ}$} & $\mathrm{d}_{1}$ & $2.302(11)$ \\
\hline & & & $\mathrm{d}_{2}$ & $2.307(11)$ \\
\hline & & & $\mathrm{d}_{3}$ & $2.307(11)$ \\
\hline & & & $\mathrm{d}_{4}$ & $2.302(11)$ \\
\hline \multirow{4}{*}{$\mathrm{U} 2-\left[\mathrm{O}_{2}\right]-\mathrm{U} 3$} & \multirow{4}{*}{$1.477(16)$} & \multirow{4}{*}{$172.6^{\circ}$} & $\mathrm{d}_{1}$ & $2.315(11)$ \\
\hline & & & $\mathrm{d}_{2}$ & $2.299(11)$ \\
\hline & & & $d_{3}$ & $2.288(11)$ \\
\hline & & & $\mathrm{d}_{4}$ & $2.319(11)$ \\
\hline \multirow{5}{*}{$\mathrm{U} 4-\left[\mathrm{O}_{2}\right]-\mathrm{U} 5$} & \multirow{5}{*}{$1.487(17)$} & \multirow{5}{*}{$154.3^{\circ}$} & $\mathrm{d}_{1}$ & $2.289(11)$ \\
\hline & & & $\mathrm{d}_{2}$ & $2.326(11)$ \\
\hline & & & & \\
\hline & & & $\mathrm{d}_{3}$ & $2.342(13)$ \\
\hline & & & $\mathrm{d}_{4}$ & $2.339(11)$ \\
\hline
\end{tabular}


Table S5. Atom compositions of the NBO orbitals of optimized $\left[\left(\mathrm{UO}_{2}\right)_{2}\left(\mathrm{O}_{2}\right)(\mathbf{P h e n})_{2}(\mathbf{P y V B})_{2}\right]$ motif.

\begin{tabular}{lllll}
\hline Bond type & $\mathrm{U} \%$ & $\mathrm{O} / \mathrm{N} \%$ & $\mathrm{U} \%$ & $\mathrm{O} / \mathrm{N} \%$ \\
\hline U1_sim-N5_sim & 7.78 & 92.22 & $7 \mathrm{~s}(18.76) 7 \mathrm{p}(1.75) 6 \mathrm{~d}(42.24) 5 \mathrm{f}(37.25)$ & $2 \mathrm{~s}(30.29) 2 \mathrm{p}(69.67)$ \\
U1_sim -N6_sim & 8.26 & 91.74 & $7 \mathrm{~s}(13.80) 7 \mathrm{p}(1.37) 6 \mathrm{~d}(38.20) 5 \mathrm{f}(46.63)$ & $2 \mathrm{~s}(31.68) 2 \mathrm{p}(68.29)$ \\
U1_sim -O7_sim & 7.38 & 92.62 & $7 \mathrm{~s}(13.89) 7 \mathrm{p}(1.80) 6 \mathrm{~d}(34.37) 5 \mathrm{f}(49.94)$ & $2 \mathrm{~s}(17.46) 2 \mathrm{p}(82.41)$ \\
U1_sim -O8_sim & 8.07 & 91.93 & $7 \mathrm{~s}(18.87) 6 \mathrm{~d}(40.10) 5 \mathrm{f}(40.06)$ & $2 \mathrm{~s}(20.48) 2 \mathrm{p}(79.41)$ \\
U1_sim -O3_sim & 8.57 & 91.43 & $7 \mathrm{~s}(7.87) 7 \mathrm{p}(1.68) 6 \mathrm{~d}(32.21) 5 \mathrm{f}(58.25)$ & $2 \mathrm{~s}(17.28) 2 \mathrm{p}(82.67)$ \\
U1_sim -O4_sim & 9.49 & 90.51 & $7 \mathrm{~s}(8.62) 6 \mathrm{~d}(31.44) 5 \mathrm{f}(59.05)$ & $2 \mathrm{~s}(20.51) 2 \mathrm{p}(79.45)$ \\
U2_sim -O3_sim & 9.04 & 90.96 & $7 \mathrm{~s}(8.72) \mathrm{p}(2.06) 6 \mathrm{~d}(35.77) 5 \mathrm{f}(53.45)$ & $2 \mathrm{~s}(17.23) 2 \mathrm{p}(82.71)$ \\
U2_sim -O4_sim & 8.60 & 91.40 & $7 \mathrm{~s}(10.93) 6 \mathrm{~d}(32.82) 5 \mathrm{f}(55.55)$ & $2 \mathrm{~s}(16.44) 2 \mathrm{p}(83.51)$ \\
U2_sim-O11_sim & 7.69 & 92.31 & $7 \mathrm{~s}(17.27) 7 \mathrm{p}(1.44) 6 \mathrm{~d}(32.56) 5 \mathrm{f}(48.73)$ & $2 \mathrm{~s}(18.18) 2 \mathrm{p}(81.69)$ \\
U2_sim-O12_sim & 7.55 & 92.45 & $7 \mathrm{~s}(19.27) 7 \mathrm{p}(2.08) 6 \mathrm{~d}(33.24) 5 \mathrm{f}(45.41)$ & $2 \mathrm{~s}(18.15) 2 \mathrm{p}(81.72)$ \\
U2_sim -N9_sim & 8.25 & 91.75 & $7 \mathrm{~s}(11.07) 7 \mathrm{p}(1.81 \%) 6 \mathrm{~d}(41.05) 5 \mathrm{f}(46.06)$ & $2 \mathrm{~s}(33.16) 2 \mathrm{p}(66.81)$ \\
U2_sim-N10_sim & 9.10 & 90.90 & $7 \mathrm{~s}(14.16) 6 \mathrm{~d}(42.30) 5 \mathrm{f}(42.80)$ & $2 \mathrm{~s}(34.02) 2 \mathrm{p}(65.96)$ \\
\hline
\end{tabular}


Table S6. Different energy data for $\left[\left(\mathrm{UO}_{2}\right)_{2}\left(\mathrm{O}_{2}\right)(\mathbf{P h e n})_{2}(\mathbf{P y V B})_{2}\right]$ motif with varying dihedral angles changing from $120^{\circ}$ to $180^{\circ}$ with the configuration at $148^{\circ}$ as a control.

\begin{tabular}{|c|c|c|c|}
\hline Dihedral angle & Relative energy & dihedral angle & Relative energy \\
\hline 180 & 1.92 & 148 & 0 \\
\hline 179 & 1.89 & 147 & 0 \\
\hline 178 & 1.86 & 146 & 0.02 \\
\hline 177 & 1.81 & 145 & 0.05 \\
\hline 176 & 1.77 & 144 & 0.10 \\
\hline 175 & 1.72 & 143 & 0.18 \\
\hline 174 & 1.67 & 142 & 0.27 \\
\hline 173 & 1.61 & 141 & 0.39 \\
\hline 172 & 1.55 & 140 & 0.54 \\
\hline 171 & 1.49 & 139 & 0.72 \\
\hline 170 & 1.42 & 138 & 0.93 \\
\hline 169 & 1.35 & 137 & 1.19 \\
\hline 168 & 1.27 & 136 & 1.48 \\
\hline 167 & 1.20 & 135 & 1.83 \\
\hline 166 & 1.12 & 134 & 2.22 \\
\hline 165 & 1.04 & 133 & 2.67 \\
\hline 164 & 0.96 & 132 & 3.19 \\
\hline 163 & 0.88 & 131 & 3.78 \\
\hline 162 & 0.80 & 130 & 4.46 \\
\hline 161 & 0.72 & 129 & 5.23 \\
\hline 160 & 0.64 & 128 & 6.10 \\
\hline 159 & 0.56 & 127 & 7.08 \\
\hline 158 & 0.48 & 126 & 8.21 \\
\hline 157 & 0.41 & 125 & 9.49 \\
\hline 156 & 0.34 & 124 & 10.94 \\
\hline 155 & 0.27 & 123 & 12.58 \\
\hline 154 & 0.21 & 122 & 14.45 \\
\hline 153 & 0.15 & 121 & 16.58 \\
\hline 152 & 0.11 & 120 & 18.99 \\
\hline 151 & 0.06 & & \\
\hline 150 & 0.03 & & \\
\hline 149 & 0.01 & & \\
\hline
\end{tabular}


Table S7. Typical hydrogen bond distances $(\AA)$ and angle $\left({ }^{\circ}\right)$ in HT-UPO1.

\begin{tabular}{|c|c|c|c|}
\hline $\mathrm{D}-\mathrm{H} \bullet \bullet A$ & $\mathrm{D} \bullet \bullet \mathrm{A} / \AA$ & $\mathrm{H} \bullet \bullet \mathrm{A} / \AA$ & Bond angle $/ \mathrm{o}$ \\
\hline $\mathrm{C} 15-\mathrm{H} 15 \cdots \mathrm{O} 4$ & $3.267(17)$ & $2.368(99)$ & 162.4 \\
\hline $\mathrm{C} 10-\mathrm{H} 10 \cdots \mathrm{O} 8$ & $3.725(25)$ & $2.943(11)$ & 142.7 \\
\hline $\mathrm{C} 73-\mathrm{H} 73 \cdots \mathrm{O} 1$ & $3.284(19)$ & $2.541(11)$ & 137.3 \\
\hline $\mathrm{C} 23-\mathrm{H} 23 \cdots \mathrm{O} 6$ & $3.286(20)$ & $2.540(11)$ & 137.2 \\
\hline $\mathrm{C} 32-\mathrm{H} 32 \cdots \mathrm{O} 2$ & $3.695(19)$ & $2.955(10)$ & 137.5 \\
\hline $\mathrm{C} 55-\mathrm{H} 55 \cdots \mathrm{O} 15$ & $3.240(18)$ & $2.348(11)$ & 160.4 \\
\hline $\mathrm{C} 48-\mathrm{H} 48 \cdots \mathrm{O} 24$ & $4.022(32)$ & $3.127(15)$ & 162.0 \\
\hline $\mathrm{C} 44-\mathrm{H} 44 \cdots \mathrm{O} 18$ & $3.752(21)$ & $2.941(14)$ & 146.5 \\
\hline C129-H129… & $3.862(21)$ & $3.082(11)$ & 142.4 \\
\hline $\mathrm{C} 84-\mathrm{H} 84 \cdots \mathrm{O} 7$ & $3.481(19)$ & $2.751(10)$ & 136.0 \\
\hline $\mathrm{C} 117-\mathrm{H} 117 \cdots \mathrm{O} 19$ & $3.476(25)$ & $2.707(14)$ & 140.6 \\
\hline $\mathrm{C} 101-\mathrm{H} 101 \cdots \mathrm{O} 17$ & $3.271(21)$ & $2.424(12)$ & 151.6 \\
\hline $\mathrm{C} 103-\mathrm{H} 103 \cdots \mathrm{O} 22$ & $4.004(20)$ & $3.128(10)$ & 157.9 \\
\hline $\mathrm{C} 130-\mathrm{H} 130 \cdots \mathrm{O} 22$ & $3.264(20)$ & $2.427(10)$ & 149.7 \\
\hline $\mathrm{C} 103-\mathrm{H} 103 \cdots \mathrm{O} 23$ & $3.997(20)$ & $3.116(11)$ & 158.8 \\
\hline $\mathrm{C} 118-\mathrm{H} 118 \cdots \mathrm{O} 25$ & $3.263(23)$ & $2.453(13)$ & 145.6 \\
\hline $\mathrm{C} 68-\mathrm{H} 68 \cdots \mathrm{N} 8$ & $3.324(32)$ & $2.633(25)$ & 131.5 \\
\hline $\mathrm{C} 29-\mathrm{H} 29 \cdots \mathrm{N} 9$ & $4.049(22)$ & $3.261(15)$ & 143.6 \\
\hline $\mathrm{C} 32-\mathrm{H} 32 \cdots \mathrm{N} 9$ & $3.860(21)$ & $3.126(15)$ & 137.1 \\
\hline C65-H65 ‥N9 & $3.377(24)$ & $2.646(17)$ & 136.0 \\
\hline
\end{tabular}


Table S8. The change of Gibbs free energies $(\Delta \mathrm{G}, \mathrm{kcal} / \mathrm{mol})$, enthalpies $(\Delta \mathrm{H}, \mathrm{kcal} / \mathrm{mol})$ and entropies $\left(\Delta \mathrm{S}\right.$, kcal/mol) for the reactions $\left(\mathrm{UO}_{2}\right)_{2}\left(\mathrm{O}_{2}\right)(\mathbf{L})_{2}+\mathrm{H}_{2} \mathrm{O}_{2}=\left(\mathrm{UO}_{2}\right)_{2}(\mathrm{OH})_{2}(\mathbf{L})_{2}+2 \mathrm{H}_{2} \mathrm{O}$ at the B3LYP/RECP/6-31G(d) level of theory.

\begin{tabular}{cccc}
\hline $\mathbf{L}$ & $\Delta \mathrm{G}$ & $\Delta \mathrm{H}$ & $10^{-3} \Delta \mathrm{S}$ \\
\hline PyVB & -429.10 & -418.15 & 36.73 \\
P4yA & -8.99 & 0.81 & 32.84 \\
P3yA & -9.87 & -0.03 & 32.98 \\
\hline
\end{tabular}




\section{References}

[1] E. Elacqua, P. Kaushik, R. H. Groeneman, J. C. Sumrak, D. K. Bucar, L. R. MacGillivray, Angew. Chem. Int. Ed. 2012, 51, 1037-1041.

[2] G. M. Sheldrick, Acta Cryst. A 2008, 64, 112-122.

[3] I. Usón, G. M. Sheldrick, Acta Cryst. D 2018, 74, 106-116.

[4] O. V. Dolomanov, L. J. Bourhis, R. J. Gildea, J. A. Howard, H. Puschmann, J. Appl. Crystallogr. 2009, 42, 339-341.

[5] a) C. T. Lee, W. T. Yang, R. G. Parr, Phys. Rev. B 1988, 37, 785-789; b) A. D. Becke, Phys. Rev. A 1988, 38, 3098-3100.

[6] M. J. Frisch, G. W. Trucks, H. B. Schlegel, G. E. Scuseria, M. A. Robb, J. R. Cheeseman, G. Scalmani, V. Barone, G. A. Petersson, H. Nakatsuji, X. Li, M. Caricato, A. V. Marenich, J. Bloino, B. G. Janesko, R. Gomperts, B. Mennucci, H. P. Hratchian, J. V. Ortiz, A. F. Izmaylov, J. L. Sonnenberg, D. Williams-Young, F. Ding, F. Lipparini, F. Egidi, J. Goings, B. Peng, A. Petrone, T. Henderson, D. Ranasinghe, V. G. Zakrzewski, G. Gao, N. Rega, G. Zheng, W. Liang, M. Hada, M. Ehara, K. Toyota, R. Fukuda, J. Hasegawa, M. Ishida, T. Nakajima, Y. Honda, O. Kitao, H. Nakai, T. Vreven, K. Throssell, J. A. Montgomery Jr., J. E. Peralta, F. Ogliaro, M. J. Bearpark, J. J. Heyd, E. N. Brothers, K. N. Kudin, V. N. Staroverov, T. A. Keith, R. Kobayashi, J. Normand, K. Raghavachari, A. P. Rendell, J. C. Burant, S. S. Iyengar, J. Tomasi, M. Cossi, J. M. Millam, M. Klene, C. Adamo, R. Cammi, J. W. Ochterski, R. L. Martin, K. Morokuma, O. Farkas, J. B. Foresman, D. J. Fox, Gaussian, Inc., Wallingford, CT, USA, 2016.

[7] X. Cao, M. Dolg, H. Stoll, J. Chem. Phys. 2003, 118, 487-496.

[8] X. Cao, M. Dolg, J. Mol. Struc.-THEOCHEM 2004, 673, 203-209.

[9] J. K. B. E. D. Glendening, A. E. Reed, J. E. Carpenter, J. A. Bohmann, C. M. Morales, C. R. Landis, and F. Weinhold, Theoretical Chemistry Institute, University of Wisconsin, Madison, WI, 2013.

[10] a) C. Fonseca Guerra, J. G. Snijders, G. te Velde, E. J. Baerends, Theor. Chem. Acc. 1998, 99, 391-403; b) G. te Velde, F. M. Bickelhaupt, E. J. Baerends, C. Fonseca Guerra, S. J. A. van Gisbergen, J. G. Snijders, T. Ziegler, J. Comput. Chem. 2001, 22, 931-967.

[11] E. Van Lenthe, E. J. Baerends, J. Comput. Chem. 2003, 24, 1142-1156.

[12] E. van Lenthe, E. J. Baerends, J. G. Snijders, J. Chem. Phys. 1993, 99, 4597-4610. 